\title{
Littoral Cell Angioma of the Spleen presenting with Thrombocytosis and Splenic Infarct
}

\author{
Nazmi Ozer and Alper Sozutek \\ Department of General Surgery, University of Health Sciences, Adana City Training and Research Hospital, Adana, Turkey
}

\begin{abstract}
Littoral cell angioma is a non-hematologic vascular neoplasm originating from littoral cells lining the splenic red pulp. The diagnosis is usually made incidentally in splenectomy materials. It is often associated with anemia and thrombocytopenia, indicative of hypersplenism. We, herein present a case of symptomatic littoral cell angioma in a 32-year female, presumed to be accompanied by a hematologic malignancy manifesting with splenic infarct and thrombocytosis.
\end{abstract}

Key Words: Littoral cell angioma, Splenic infarct, Thrombocytosis.

How to cite this article: Ozer N, Sozutek A. Littoral Cell Angioma of the Spleen presenting with Thrombocytosis and Splenic Infarct. J Coll Physicians Surg Pak 2021; 31(08):986-988.

\section{INTRODUCTION}

Littoral cell angioma, described by Falk et al. in 1991, is a non-hematologic vascular neoplasm that originates from the littoral cells in the red pulp of spleen with dual characteristics of endothelial-histiocytic cells. ${ }^{1,2}$ Its pathological examinations show vascular proliferation in the spleen in the same manner as sinusoids; and it differs from angiosarcoma by the low index of Ki-67 staining. In addition, in immunohistochemical examinations, positivity of $C D 68$ and $C D 31$, and negativity of $C D 8$ and $C D 34$ is diagnostic for this lesion. ${ }^{3}$

Littoral cell angioma may be associated with visceral malignancies such as thyroid, colorectal, renal, ovarian and testicular tumors as well as hematologic malignancies. ${ }^{4-7}$ Clinically, patients present to the hospital with abdominal pain and splenomegaly. Anemiaand thrombocytopeniacaused by hypersplenism are observed in the blood parameters. ${ }^{8-10}$ We, report a case of littoral cell angioma associated with thrombocytosis and splenic infarction. The splenic infarct and thrombocytosis instead of thrombocytopenia at presentation, are being reported for the first time for littoral cell angioma in the literature to the best of ourknowledge.

\section{CASE REPORT}

A 32-year female patient presented to the Emergency Department due to the complaints of abdominal pain, nausea, and vomiting that had been continuing for a week.

Correspondence to: Dr. Nazmi Ozer, Department of General Surgery, University of Health Sciences, Adana City Training and Research Hospital, Adana, Turkey E-mail: nazmiozer83@gmail.com

Received: October 07, 2019; Revised: December 20, 2019; Accepted: December 30, 2019

DOI: https://doi.org/10.29271/jcpsp.2021.08.986
Physical examination revealed tenderness in the left upper quadrant of the abdomen. Traube's space was closed. The spleen was palpable below the ribs. The patient had a normal medical and family history. In her laboratory results, C-reactive protein (CRP) was $112 \mathrm{mg} / \mathrm{dl}$ and lactate dehydrogenase (LDH) was $651 \mathrm{U} / \mathrm{L}$, both of which were high. Other biochemical values were normal. In hemogram, white blood count (WBC) was $12.1 \times 10^{3} / \mu \mathrm{L}$, hemoglobin $(\mathrm{Hb})$ was $10.3 \mathrm{~g} / \mathrm{dl}$, and platelets were $1012 \times 10^{3} / \mu \mathrm{L}$.

In abdominal ultrasonography, the splenic long axis was $21 \mathrm{~cm}$ and its size was increased. The splenic parenchyma was heterogeneous, and the splenic vein diameter was increased. The patient underwent a contrast-enhanced abdominal $\mathrm{CT}$, which showed massive splenomegaly $(93 \times 185 \mathrm{~mm})$, increase in splenic vein caliber, varicosis and tortoise changes in splenic hilum, and a single $7 \mathrm{~cm}$ hypodense lesion associated with sporadic necrotic areas at the widest part of the spleen body (Figure 1). Decision for splenectomy was made.

The abdomen was opened by a left subcostal incision under general anesthesia. Spleen was separated from adhesions in surrounding tissues. After the adhesions were removed, the hilar artery and vein were isolated and ligated; and splenectomy was performed. Splenectomy revealed infarcted areas in the spleen. The patient was discharged with full recovery on postoperative day 7 .

The pathological examination reported an infarcted vascular neoplasm and concomitant extramedullary hematopoiesis compatible with littoral cell angioma. Immunohistochemistry showeda positive reaction to CD31, CD68, CD163, CD4 and negative reaction to $C D 8$ and $C D 34$. Ki-67 proliferation index was low (Figures 2 and 3 ).

Postoperatively, Doppler ultrasonography showed appearances consistent with thrombosis in the portal vein and its branches. Bone marrow aspiration biopsy indicated dysplasia in the megakaryocytic series and an increase in fibrosis of grade 2 retic- 
ulin staining. Platelet counts remained very high during the postoperative period $\left(4000 \times 10^{3} / \mu \mathrm{L}\right)$.

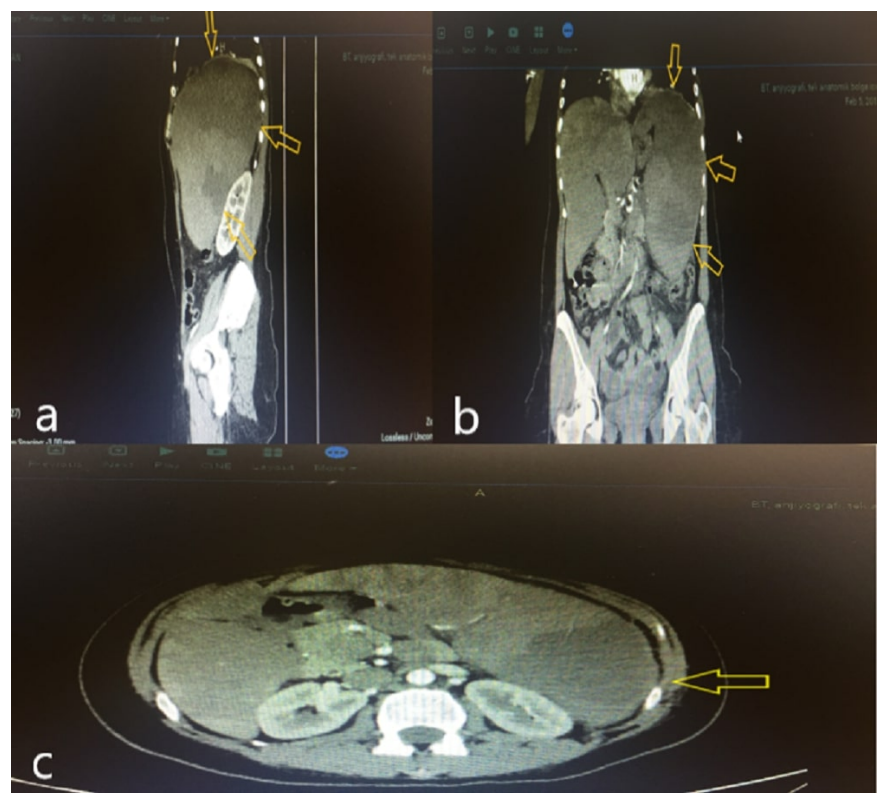

Figure 1: Contrast-enhanced abdominal CT. (a) Sagittal section, (b) Coronal section; (c) Axial section. There is a mass lesion accompanied by heterogeneous hypodense areas marked with a yellow arrow.

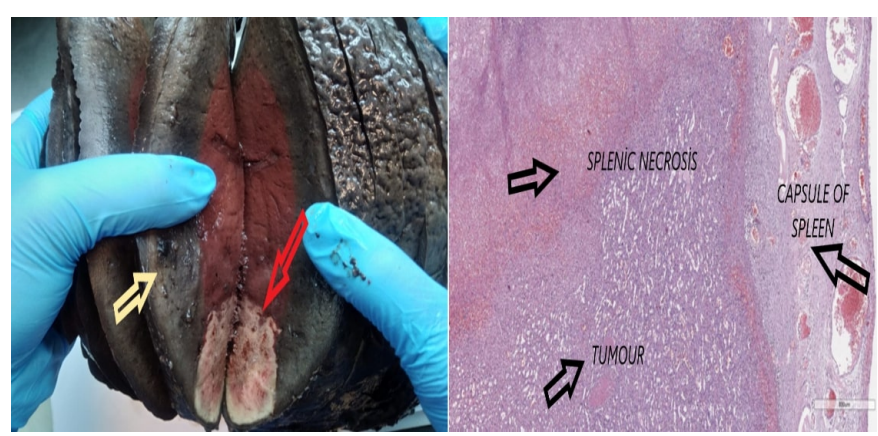

Figure 2: Macroscopic (infracted areas with yellow arrow, tumoral tissue with red arrow) and microscopic view of tumoral tissue and infarcted area (H\&EStain $\times 100)$.

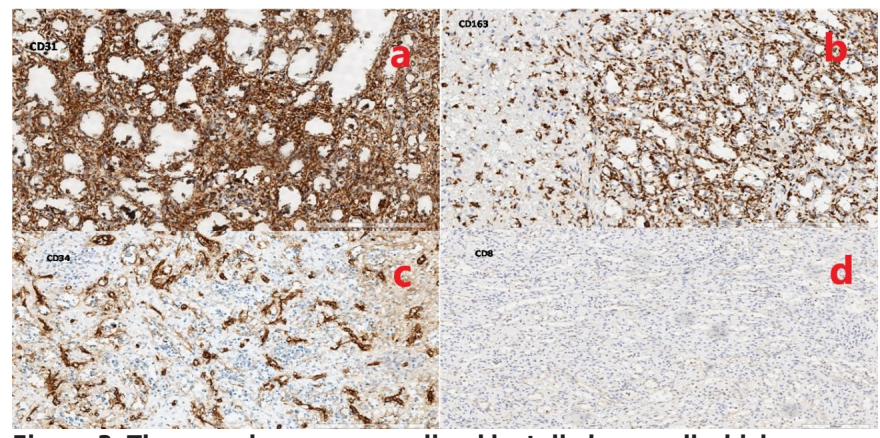

Figure 3: The vascular spaces are lined by tall plump cell which express both endothelial and histiocytic markers. İmmünohistochemical stains showed that the intrasinusoidal histiocytic cells expressed CD31 (a), CD163 (b), but were negative for CD34 (c) and CD8 (d).

\section{DISCUSSION}

Littoral cell angioma is a benign lesion originating from littoral cells lining the splenic red pulp. It is often seen incidentally in splenectomy materials performed for other reasons. ${ }^{1}$
In the immunohistochemical examination, positivity for CD 4 and $C D 68$ and negativity for $C D 8$ and CD 34 have a diagnostic value for littoral cell angioma. ${ }^{3}$ Our immunohistochemical findings were consistent with those reported in the literature.

Clinically, patients present to the hospital with abdominal pain and splenomegaly. Anemia and thrombocytopenia, caused by hypersplenism, are typically observed in examinations.$^{8-10}$ Our case is a rare and unique one, as it was accompanied by thrombocytosis, contrary to thrombocytopenia reported in the literature.

Bone marrow aspiration biopsy suggested that a hematologic malignancy with a tendency to thrombosis may have been associated with littoral cell angioma, but

definitive diagnosis of malignancy could not be made because the patient refused further examination during hematologic examination.

In addition, splenic infarction has not been reported previously with littoral cell angioma and is of great significance to be reported in the literature. In our opinion, the hematological disease leading to thrombocytosis may have caused splenic thrombosis and infarction.

In summary, this case emphasises the fact that littoral cell angioma, a rare non-hematologic vascular tumor in the spleen, may rarely present with thrombocytosis instead of thrombocytopenia; and may possibly be associated with splenic infarction and hematologic malignancies.

\section{PATIENT'S CONSENT:}

Informed consent was obtained from the patient.

\section{CONFLICT OF INTEREST:}

The authors declared no conflict of interest.

\section{AUTHORS' CONTRIBUTION:}

NO: Concept, supervision, interpretation, writing manuscript, critical reviews.

AS: Design, data collection and processing, literature search.

\section{REFERENCES}

1. Lin XY, Li JM, Wang QX, Feng JZ, Zhao MQ, Zhong WX, et al. Littoral cell angioma of the spleen: Report of three cases and a review of the literature. Chin Med J (Engl) 2011; 124(20):3423-6.

2. Falk S, Stutte HJ, Frizzera G. Littoral cell angioma. A novel splenic vascular lesion demonstrating histiocytic differentiation. Am J Surg Pathol 1991; 15(11):1023-33.

3. Arber DA, Strickler JG, Chen YY, Weiss LM. Splenic vascular tumors: a histologic, immunophenotypic, and virologic study. Am J Surg Pathol 1997; 21(7):827-35. doi: 10.1097/00000478-199707000-00011.

4. Gupta MK, Levin M, Aguilera NS, Pastores GM. Littoral cell angioma of the spleen in a patient with Gaucher disease. Am J Hematol 2001; 68(1):61-2. doi: 10.1002/ajh.1151.

5. Harmon RL, Cerruto CA, Scheckner A. Littoral cell angioma: a case report and review. Curr Surg 2006; 63(5):345-50. 
doi: 10.1016/j.cursur.2006.06.011.

6. Bisceglia M, Sickel JZ, Giangaspero F, Gomes V, Amini M, Michal M. Littoral cell angioma of the spleen: An additional report of four cases with emphasis on the association with visceral organ cancers. Tumori 1998; 84(5):595-9.

7. Akyildiz H, Akcan A, Soyuer I, Karahan OI, Sozuer E. Littoral cell angioma mimicking pancreatic tumor. Surgery 2007; 141(5):690-1. doi: 10.1016/j.surg.2006.04.017.

8. Priego P, Rodríguez Velasco G, Griffith PS, Fresneda V.
Littoral cell angioma of the spleen. Clin Transl Oncology 2008; 10(1):61-3. doi: 10.1007/s12094-008-0155-3.

9. Liang W, Lu J, Qin M, Sang X. Littoral cell angioma mimicking hepatic tumor. Acta Radiol Short Rep 2012; 1(16): arsr.2012.120031. doi: 10.1258/arsr.2012. 120031. eCollection 2012.

10. Chourmouzi D, Psoma E, Drevelegas A. Littoral cell angioma, a rare cause of long standing anaemia: A case report. Cases J 2009; 2:9115-8. doi: 10.1186/17571626-2-9115. 